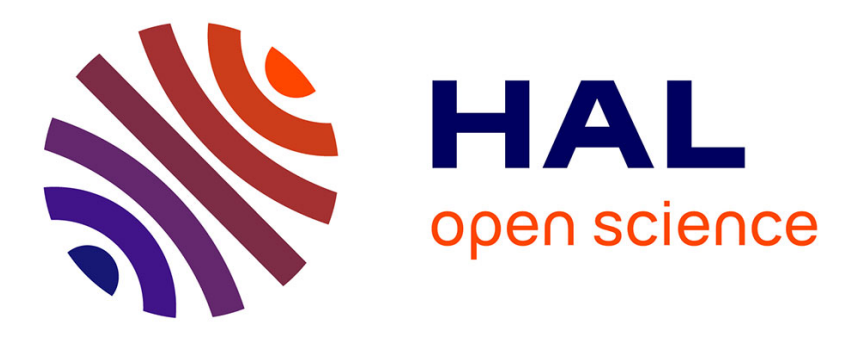

\title{
Conditional clauses, Main Clause Phenomena and the syntax of polarity emphasis
}

\author{
Lieven Danckaert, Liliane Haegeman
}

\section{To cite this version:}

Lieven Danckaert, Liliane Haegeman. Conditional clauses, Main Clause Phenomena and the syntax of polarity emphasis. Ackema, Peter; Alcorn, Rhona; Heycock, Caroline; Jaspers, Dany; van Craenenbroeck, Jeroen; Vanden Wyngaerd, Guido. Comparative Germanic syntax: the state of the art, John Benjamins, pp.133-167, 2012, Comparative Germanic syntax: the state of the art, 9789027255747. 10.1075/la.191.05dan . halshs-01534968

\section{HAL Id: halshs-01534968 https://shs.hal.science/halshs-01534968}

Submitted on 8 Jun 2017

HAL is a multi-disciplinary open access archive for the deposit and dissemination of scientific research documents, whether they are published or not. The documents may come from teaching and research institutions in France or abroad, or from public or private research centers.
L'archive ouverte pluridisciplinaire HAL, est destinée au dépôt et à la diffusion de documents scientifiques de niveau recherche, publiés ou non, émanant des établissements d'enseignement et de recherche français ou étrangers, des laboratoires publics ou privés. 


\title{
Conditional clauses, Main Clause Phenomena and the syntax of polarity emphasis*
} Lieven Danckaert and Liliane Haegeman

Short title: Conditionals, MCP and polarity emphasis

\begin{abstract}
This paper addresses two properties of conditional clauses: (i) their incompatibility with Main Clause Phenomena, exemplified by English argument fronting, and (ii) the unavailability of Speaker Oriented Adverbs (Ernst 2009) (SpOA). The paper elaborates the hypothesis (Bhatt and Pancheva 2002, 2006) that conditional clauses are derived by operator movement. The absence of MCP follows from locality conditions.

Adopting the cartographic approach to SpOAs developed in Cinque (1999), it is proposed that the operator which derives conditionals originates in SpecMood $\operatorname{Sirrealis}_{\text {. This }}$ specific implementation of the movement derivation will account for the unavailability of SpOAs in conditional clauses.

The final part of the paper extends the range of MCP: it shows that polarity emphasis is not a homogeneous phenomenon: certain expressions of emphatic polarity are MCP and hence unavailable in conditional clauses, while others are not restricted to root domains.
\end{abstract}

Key words: conditionals, cartography, intervention, polarity emphasis.

Lieven Danckaert

Linguistics department

Ghent University/FWO

Blandijnberg 2

B-9000 Ghent

Belgium

Lieven.danckaert@UGent.be

liliane.haegeman@UGent.be
Liliane Haegeman 


\section{Introduction: Scope and organization of the paper}

\section{Conditional clauses: two observations}

This paper focuses on two patterns displayed by antecedents of conditional clauses (which we will refer to from now as 'conditional clauses') which have been discussed in the literature.

(i) In English, conditional clauses are incompatible with argument fronting, as illustrated in (1a) (Hooper and Thompson 1973, Emonds 1970, 1976, Emonds 2004, Maki et al. 1999):

(1) a. *If these exams you don't pass, you won't get the degree.

(ii) Conditionals are also incompatible with speaker-oriented adverbials ( $\mathrm{SpOA})$, for recent discussions see Nilsen (2004), Ernst (2009), as shown in (1b):

(1) b. ??*If frankly he's unable to cope, we'll have to replace him.

\subsubsection{Argument fronting in conditional clauses}

The absence of argument fronting in English (1a) is part of a comprehensive restriction on the left periphery (LP) of adverbial clauses, in that they are incompatible with so called Root Transformations (Emonds 1970) or Main Clause Phenomena (MCP), that is phenomena that are restricted to main clauses and a subset of complement clauses. Other MCP which are also incompatible with conditional clauses are locative inversion, preposing around $b e$, VP topicalization, ${ }^{1}$ as illustrated in (2):

(2) a. *If upstairs live his parents things will be much simpler.

b. $\quad *$ If present at the party are under age children, they won't be able to show the X-rated films.

c. $\quad *$ If passed these exams you had, you would have had the degree.

These phenomena were first inventoried and described in Emonds's seminal work (1970, 1976). For recent discussion see Emonds (2004) and Heycock (2006).

One might conclude from the restricted distribution of MCP that conditional clauses lack a left peripheral 'space' entirely, that is that the conjunction if is merged directly with TP, but this hypothesis is problematic because conditional clauses are compatible with adjuncts appearing to the left of the subject. In (2d) and the attested (2e), the PPs by Monday and on Monday precede the canonical subject position. If, as has been argued by, among others, Rizzi (1997), Aboh (2004 : 312), and Endo (2007: 76), fronted adjuncts are topicalized, then data such as $(2 \mathrm{~d})$ and $(2 \mathrm{e})$ mean that conditional clauses are compatible with a topicalization, raising the question why (1a) is not grammatical.

(2) d. If by Monday we haven't found him, we'll call the RSPCA.

e. If on Monday the share price is still at the current level then clearly their defence doesn't hold much water. (Observer, 11.7.4, business, $\mathrm{p}$. 22 col 5) 
Further support for the hypothesis that adverbial clauses do have a left peripheral space comes from the Romance languages, in which clitic left dislocation, which is also commonly taken to be associated with a left peripheral topic projection (Rizzi 1997), is available in conditional clauses. This is shown in Italian (3a), Catalan (3b), Spanish (3c) and French (3d), all from Haegeman (2006). CLLD is also available in Greek conditional clauses, as shown in (3e):
a.
Se gli esami finali non li superi,
non otterrai
il diploma.
if the final exams non them pass-2sG, non obtain-FUT-2SG the diploma 'If you don't pass the final exams, you won't get the diploma.' (Haegeman 2006: (22a))
b. Si aquest examen no l'aproves amb un cinc, if this exam no it pass-2SG with a five, perdràs el curs sencer. lose-FUT-2SG the course entire 'If you don't pass this exam with a 5, you'll miss the whole year.' (Haegeman 2006: (23a))
c. Si este examen no lo apruebas con un cinco, if this exam no it finish-2SG with a five, perderás el curso entero. lose-FUT-2SG the course entire 'If you don't pass this exam with a 5, you'll miss the whole year.' (Haegeman 2006: (24))
d. $\%$ Si ce livre-là tu le trouves à la Fnac, achète-le. ${ }^{2}$ if this book there you it find-2SG at the Fnac, buy-it. 'If here you find this book at the FNAC, buy it' (Haegeman 2006: (25))
e. An afto to vivlio to vris stin dhimotiki vivliothiki, if this the book it find-2sG in-the local library boris na to paraggilis stin kentriki vilviothiki. ${ }^{3}$ could-2SG- PRT it order-2SG in-the central library 'If you find this book at the local library, then you can order it in the central library.' (Haegeman 2006: (26))

\subsubsection{Modal markers in conditional clauses}

(4) contains some examples from the literature which illustrate the incompatibility of conditional clauses with SpOAs (see also Ernst (2009) for more subtle discussion). Typically, speech act adverbs such as frankly (1b), repeated as (4a), evaluative adverbs such as luckily and fortunately $(4 \mathrm{~b}, \mathrm{c})$, epistemic adverbs such as probably $(4 \mathrm{~d})$, and evidential adverbs such as apparently (4e), as well as the modal auxiliaries with the same types of meaning (4f), are incompatible with a conditional clause.

(4) a. ??*If frankly he's unable to cope, we'll have to replace him.
b. $\quad *$ If they luckily /fortunately arrived on time, we will be saved. (Ernst 2007: 1027, Nilsen 2004).
c. *If George unfortunately/oddly comes, the party will be a disaster. (Ernst 2009: his (55c))
d. $\quad *$ If George probably comes, the party will be a disaster.
e. $\quad *$ If the students apparently can't follow the discussion in the third chapter, we'll do the second chapter.


f. * John will do it if he may/must have time. (Declerck and Depraetere (1995: 278), Heinämäkki (1978: 22), Palmer (1990: 121, 182))

This pattern is not exclusive to English (see Ernst (2009) on French, Chinese and Dutch, Haegeman (2006c) on evidential sembrare in Italian, etc.). Ernst (2009) rejects a syntactic account of the data in (4): the "F-Spec account [such as Cinque's (1999) account, d\&h] has nothing to say about why SpOAs are usually bad in ...the antecedents of conditionals." (Ernst 2009: 504). He continues: "Such facts may be treated as a purely semantic matter (...) but for the F-Spec approach a semantic explanation must be an add-on to the basic syntactic account" (Ernst 2009: 504). This paper develops a syntactic account for the incompatibility of conditional antecedents with high modal markers.

\subsection{Goal and organization of this paper}

This paper argues that both the absence of argument fronting and that of SpOAs in conditional clauses can be made to follow from proposals according to which conditional clauses are derived by leftward movement of an operator to the LP. The paper is organised as follows: Section 2 discusses the absence of high modals and of argument fronting in conditional clauses. Section 3 shows that the argument/adjunct asymmetry observed for English conditional clauses and the compatibility of conditional clauses with CLLD are reminiscent of intervention effects observed in the derivation of interrogative clauses and conditional clauses. Section 4 elaborates the proposal that conditional clauses be derived as free relatives. Section 5 shows how a particular implementation of the movement account can derive the incompatibility of conditional clause with high modals. Section 6 shows that while some markers of emphatic polarity have a restricted distribution, others are not so restricted and accounts for the difference in terms of their syntax. Section 7 is a short conclusion.

\section{Argument fronting and high modals}

\subsection{A correlation}

In the literature it has sometimes been argued that the absence of fronting phenomena and that of SpOAs are related. For instance, concerning Korean and Japanese, Whitman (1989) signals that "modals are also blocked from appearing in the embedded contexts which disallow topics" (Whitman 1989: 345). Bayer (2001) formulates a more explicit hypothesis to link the two:

... this form of [emphatic, $d \& h$ ] topicalization is the grammar's reflex of the speech act to be performed and is as such on a par with German constructions involving modal particles like aber, denn, doch, ja etc. Modal particles supply features which interact with other features such as $[\mathrm{WH}]$ yielding a wide range of illocutionary forces. (Bayer, 2001: 14-15)

....if emphatic topicalization belongs to the class of grammatical means of force projection in the sense of Rizzi (1997), its root clause property and strict left peripherality [in Bavarian] are not surprising. (Bayer 2001: 14-15)

Hrafnbjargarson (2008) also postulates a correlation between topicalization and the occurrence of modal markers in complement clauses. 


\subsection{The assertion hypothesis}

One way of tying together the absence of MCP and that of SpOAs in conditional clauses is the Assertion hypothesis elaborated in Hooper and Thompson (1973):

As a positive environment we can say that [root] transformations operate only on Ss that are asserted. ...some transformations are sensitive to more than just syntactic configurations. (Hooper and Thompson 1973: 495)

That topicalization depends on assertion is proposed in Krifka (2001) and is adopted by Bayer (2001), who also relates it to the availability of speaker related modality. If conditional clauses are not asserted, a plausible hypothesis, the absence of MCP follows.

Haegeman (2003b, 2006a) proposes that SpOAs also depend on assertion. Similar conclusions are reached by Ernst (2009) and Zagona (2007). The latter expresses the dependency of high modals on assertion in terms of feature checking.

The conditional clauses in (1)-(4) illustrate which were called 'event' conditionals inHaegeman (2003) or 'central' conditionals in Haegeman (2007). They express conditions on the occurrence of the event expressed in the associated main clause. Central conditionals differ from 'peripheral' conditionals such as that illustrated in (5a), which bring to the fore a proposition that is available in the discourse background.

(5) a. We are seeing a fall in the incidence of crime, particularly serious crime, and I think we're right to say 'What's going on?' If crime is falling, why are we seeing a continuing rise in the prison population? (Guardian, 01.11.01, page 2, col 6)

Peripheral conditionals are typically echoic, as also indicated in Declerck and Reed (2001).

closed P-clauses [ $\approx$ peripheral conditional clauses, $\mathrm{d} \& \mathrm{~h}]$ are always echoic in one sense or another. They can echo straightforward statements about the actual world, or they can echo Q-propositions about a nonfactual world. However, the claim that closed Ppropositions are echoic need not mean that they have to be echoes of actual utterances. They may also be echoes of an internal or mental proposition (thought) such as the interpretation of an experience, perception etc. (Declerck and Reed 2001:83)

Haegeman $(2003,2006 b, 2006 c)$ signals that peripheral conditionals are compatible with MCP (5b) and with SpOAs (5c). This is not surprising: peripheral conditionals encode the speaker's commitment to a proposition already accessible in the discourse, so one might propose that, crucially, peripheral conditionals are assertions (see Kearns (2006) for 'conditional assertion').

(5) b. If some precautions they have indeed taken, many other possible measures they have continued to neglect.

c. If Le Pen will probably win, Jospin must be disappointed. (Nilsen 2004: 811: note 5)

Though relating MCP, SpOAs and assertive force may be a promising move, the use of the concept 'assertion' as a distinctive property is not without its problems. For one thing, as shown, for instance, in Heycock (2006), Bentzen et al. (2007a, 2007b), Wiklund (2009)etc., the concept itself is notoriously elusive, leading often to circular reasoning of the type that a 
clause which contains either an MCP or an SpOA is dubbed 'assertive' without there being independent diagnostics. A second problem for the assertion approach is the observation that conditional clauses are compatible with CLLD (cf. (3)). CLLD is usually considered as an expression of topicalization (with a number of subclasses as discussed in Frascarelli and Hinterhölzl (2007), and also in Bianchi and Frascarelli (2009)), so the very availability of data such as those in (3) casts doubt on the assumption that topicalization necessarily depends on assertion.

One option might be to claim that the LP of languages with CLLD is somewhat richer and allows for CLLD in conditional clauses, while the LP of English conditional clauses is somehow impoverished (cf. Emonds 2004). However, observe that in Italian, in which CLLD is available in conditional clauses, other types of preposing remain unavailable in the same domain, as shown by Bocci (2007) for focalization (6a), and by Cardinaletti (2008) for 'resumptive preposing' (6b). Furthermore, Garzonio (2008) shows that while in the unmarked case, PP proposing seems to optionally require a resumptive clitic in the TP domain, the clitic becomes obligatory in a conditional clause (6c). See also Cruschina (2010).
a.
??Se LA PROVA ORALE non supera, non otterrà
il diploma!
if THE ORAL EXAM non pass-2SG, non get-FUT-3SG the diploma 'If she does not pass the oral exam, she won't get the diploma.!' (Bocci 2007: his (32))
b. * Se la stessa proposta fa anche l'altro candidate, If the same proposal makes also the other candidate, non otterrai quel posto. non obtain-FUT-2SG that position 'If the other candidate also makes that proposal, you won't get the position.' (Cardinaletti 2008: (19a))
c. Se, col capo, non * (ci) parli, non puoi capire il problema. if with-the head, non *(him) talk-2SG, non can-2SG understand the problem 'If you don't talk with the boss, you can't understand the problem.' (Garzonio 2008: 5, his (9c))

In order to capture such data a refined approach to the LP would be required to ensure that while there is a projection that allows for CLLD in conditional clauses, the projection that hosts English type argument fronting is unavailable. In previous work (Haegeman 2003, 2006a) such an account was developed, but as discussed in Haegeman (2007, 2010a) the proposal leads to problems of implementation. For reasons of space we will not go into this point here and we refer to Haegeman (2007, 2010a) for discussion.

One problem, not signaled in the earlier discussion, is that while in English fronting a focused constituent is not possible in conditional clauses, in situ focus and clefting are available. This would mean that focusing is not necessarily dependent on assertion unless, with Duffield (2007) we postulate a lower Assertion head. But the latter strategy obviously raises a complication for the truncation analysis. ${ }^{4}$

(7) a. *If JOHN you invite (rather than Peter), things will work out fine.

b. If you invite JOHN, things will work out fine.

c. (Either John or Mary will be chair the meeting.) If it's JOHN who chairs the meeting, then we'll finish on time.

\section{An intervention account}




\subsection{A double asymmetry}

(1a) and (2d) and Italian (3a) are repeated in (8) and summarized schematically in (9). They display a double asymmetry: (i) English fronted arguments differ from initial adjuncts, and (ii) English fronted arguments differ from Romance CLLD. This double asymmetry is not restricted to conditional clauses. It is found in a range of other environments, discussed in the next sections. ${ }^{5}$

(8) a. *If these exams you don't pass, you won't get the degree.

b. If by Monday we haven't found him, we'll call the RSPCA.

c. Se gli esamifinali non li superi, non otterrai il diploma. if the exams final-PL non them pass-2SG, non obtain-FUT-2SG the degree 'If you don't pass the final exams, you won't get the degree.'

(9) a. Eng *if-argument..................

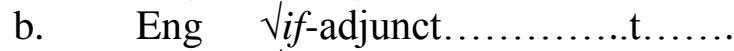

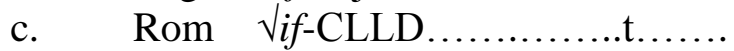

\subsection{Temporal adverbial clauses}

The double asymmetry shown in (9) is also found in temporal adverbial clauses: such clauses resist argument fronting (10), they allow adjunct preposing (11), and in the relevant languages CLLD is grammatical (12):

(10) a. *When her regular column she began to write again, I thought she would be OK.

b. $\quad$ *I won't take time off until this handout I have finished.

(11) a. When last Monday he hadn't come back, we called the RSPCA.

b. I used to work on an old desktop until one day that was stolen and...
a.
Dès que
ton texte je l'aurai
lu, je t'appellerai .
as soon as your text I it have-FUT-1SG read, I you call-FUT-1SG
'As soon as I have read your text, I will call you.'
b. Quand ça, je l'ai appris, j'ai immédiatement téléphoné
when that I it have-1SG heard, I have-1SG immediately called à la police.
the police
'When I have heard that, I have immediately called the police.'

\subsection{Embedded interrogatives}

Furthermore, the double asymmetry in (9) is displayed by embedded interrogatives, as shown in (13)-(15): ${ }^{6}$

(13) a. *Robin knows where, the birdseed, you are going to put. (Culicover 1991: 5, his (6c))

b. $\quad$ *I wonder who, this book, would buy around Christmas. (Rizzi 1997: 307, his (76a))

c. $\quad *$ I don't know when your text we will be able to discuss.

(14) Lee forgot which dishes, under normal circumstances, you would put on the table. (Culicover 1991: 9, his (17d))

a. J'aimerais savoir à qui ton texte, tu comptes le montrer. 
I like-COND-1SG know to whom your text you count-2SG it show.

'I would like to know to whom you are thinking of showing your text.'

b. Je ne sais pas quand, ton texte, on pourra le discuter.

I ne know not when, your text, one can-FUT-3SG it discuss

'I don't know when we will be able to discuss your text.'

\subsection{Relative clauses}

Relative clauses also display the double assymetry in (9), as shown in (16)-(18):

(16) a. ??He is a man from whom money we could never take. (Bianchi 1999: 188, her (76))

(17) a. This is the student to whom, last week, I had recommended your book.

b. They build machines that, during lunch hours, businessmen can exercise on. (Emonds 1976: 196)

(18) a. ? lo studente a cui, il tuo libro, lo darò domani the student to whom, the your book, it give-FUT-1SG tomorrow 'the student to whom I'll give your book tomorrow'

b. Voici l'étudiant àqui ton livre je le donnerai this is the student to whom your book I it give-FUT-1SG la semaine prochaine. next week 'This is the student to whom I'll give your book next week.'

\subsection{Argument fronting and intervention}

Both interrogative clauses and relative clauses are standardly taken to be derived by leftward movement of an operator to the LP. The double asymmetry in embedded interrogatives (3.3.) and relatives (3.4.) is usually accounted for in terms of the movement derivation: fronted arguments block the movement of the $w$ h-operator $(13,16)$, while neither adjuncts $(14,17)$ nor CLLD constituents $(15,18)$ block operator movement.

The same intervention effect is expected to obtain in the case of long movement and hence we predict the double asymmetry to arise in such contexts too. This is confirmed in (19)-(21): fronted arguments create islands for long movement (19a), fronted adjuncts (20) and CLLD (21) do not block long movement.

The long movement data cast doubt on the validity of the assertion hypothesis for the double asymmetry. While indeed embedded interrogatives (cf. (13)) are by their very interrogative nature not asserted, a finite clause embedded under suggest is intrinsically compatible with argument fronting (19b):

(19) a. *??These are the patients to whom Mary suggested that the cooked vegetables we should give in the present circumstances.

b. Mary suggested that the cooked vegetables we only give to the younger patients.

(20) These are the patients to whom Marty suggested that in the present circumstances we should give the cooked vegetables.

(21) ? Non so a chi pensi che, tuo fratello, lo potremmo affidare. Non know-1SG to whom think-2sg that your brother him can-COND-1PL entrust 
'I don't know to whom you think that, your brother, we could entrust' (Rizzi 2002: his (64a))

\subsection{A feature based account of the double asymmetry}

\subsubsection{Features and intervention}

In this section we briefly sketch the type of locality theory required to account for the intervention effects observed. Different implementations are conceivable, but these are not crucial for the matter at hand.

It is generally agreed that in English the manner adjunct how cannot be extracted across whether (22a), while extraction of which problem in (22b) and relativization in (22c) are possible. In order to account for this contrast, concepts such as D-linking, referentiality, argument-status, thematic status, specificity, presuppositionality, topicality have been invoked in the literature (cf. Cinque 1990, Rizzi 2001, Starke 2001, Miyagawa 2004, Grohmann 2005, Endo 2007 etc.)

(22) a. *How do you wonder whether John will solve the problem?

b. ?Which problem do you wonder whether John will solve?

c. ?These are the problems which I wonder whether John will solve.

The intuition is that extraction out of a weak island (as that created by whether in (22)) is facilitated by an additional discourse-related property. Following Haegeman (2010a), we represent the additional factor by the symbol $\delta ; \delta$ may either be a unitary factor or perhaps several of the ingredients listed above may be involved (cf. Starke 2001).

According to classical intervention, a constituent with the feature $\alpha$ blocks the extraction of a constituent with the same feature. In line with Starke (2001) and Rizzi (2004), we adopt the hypothesis that the blocking effect induced by an intervening $\alpha$ can be overcome if the moved constituent has an additional feature (here $\delta$ ). To account for the patterns in (22), summarized in (23), we assume that wh-phrases, including whether, are associated with an operator feature, represented as Q. In (23a), Q on whether blocks a probing relation between a higher probe and a lower wh-constituent with Q. In $(23 \mathrm{~b}, \mathrm{c})$ the blocking effect of $\mathrm{Q}$ is overcome once the probe/goal relation is constructed on the basis of the combination of $\mathrm{Q}$ and the additional $\delta$ :
a. Q
whether
$\mathrm{wh}_{\text {int }}$
b.
whether
Q
$\mathrm{Q}+\delta$
Q
$\mathrm{wh}_{\text {int }}, \mathrm{D}$-linked
c.
whether
$\mathrm{Q}+\delta$
$\mathrm{Q}$
Rel
$\mathrm{Q}+\delta$
Q
$\mathrm{Q}+\delta$

\subsubsection{The argument/adjunct asymmetry}

In English, fronted arguments consistently create islands for $w h$-extraction (24a,b,c), while they themselves can extract from weak islands (24d):

(24) a. *Who did you say that to Sue Bill introduced (Boeckx and Jeong 2004:

(3)) 
b. *How do you think that, this problem, we can solve?

c. $\quad *$ This is a student to whom, your book, I will recommend.

d. ?This problem, I wonder whether John will be able to solve.

Since fronted arguments prevent $w h$-extraction they must share a relevant feature with $w h$ constituents. We assume that this is the feature Q. That fronted arguments can overcome the weak island created by whether in (24d) suggests that these arguments are like D-linked and hence associated with $\delta$, allowing them to escape the WI. Hence, English fronted topics have the features $\delta+Q$ (Boeckx and Jeong 2004: 18), and by virtue of this specification they will be interveners both for constituents with the feature Q (i.e. 'pure' wh-operators) as well as for those with the specification $\delta+\mathrm{Q}$ (i.e. D-linked $w h$-operators and topicalised DPs).

Sentence-initial circumstantial adjuncts do not give rise to the same type of intervention. One option to account for this contrast is by postulating that circumstantial adjuncts can be merged directly in the LP and hence that they lack the relevant operator feature that triggers movement. However, observe that circumstantial adjuncts can be associated with operator features. This is clearest in cases in which they have undergone long movement as shown in (25) (cf. Haegeman 2003b, Postal and Ross 1971, Cinque 1990: 9395, Bouma, Malouf and Sag 2001, Hukari and Levine 1995):

(25) a. By tomorrow I think the situation will be clear.

b. Next year the President believes that there will be a definite improvement in the functioning of the financial system.

In these examples the fronted adjuncts must have low construal, a property which we can relate to them having moved from the lower clause to the matrix domain. As shown in Haegeman (2003b), as far as intervention effects are concerned, long-moved adjuncts pattern with fronted arguments. For instance, like fronted arguments (16), long fronted adjuncts lead to intervention effect for relativization. In (26) the fronted adjunct during my time as University president cannot be construed with the lower clauses.

(26) These are the investigators who, during my time as University president, I told there were never any illegitimate appropriations of money.

Long fronted adjuncts also create islands for extraction. In the examples in (27) the fronted adjunct in the present circumstances cannot be construed with the embedded domain 'we will only give the cooked vegetables'.

(27) a. To these patients I suggest that in the present circumstances you announce that we will only give the cooked vegetables.

b. To which patients did he suggest that in the present circumstances you announce that we will only give the cooked vegetables?

Long extracted adjuncts are not compatible with central conditional clauses: in (28) this afternoon cannot be construed with the embedded clause 'it will rain':

If this afternoon they say that it will rain, we won't go.

We will therefore assume that a locally construed initial circumstantial adjunct can be merged in situ. When an initial circumstantial adjunct has low construal, it has been moved, in which case it patterns with topicalised and focalised arguments, it will have the relevant 
features and will lead to intervention. We take the contrast between the adjuncts with local construal and those with low construal to be support for the proposal that adjuncts with local construal can be merged directly in the LP. ${ }^{7}$

\subsubsection{The argument /CLLD asymmetry}

The fronted argument in the CLLD construction must be featurally distinct from fronted arguments in English, since it does not lead to intervention effects. Quoting Rizzi: 'If topics form a separate class from other A' dependencies, we predict that we will not find locality interactions with other types of A' dependencies.' (Rizzi 2004: 245ff.) Because CLLD topics do not intervene in $w h$-fronting, a (CLLD) topic ( $a$ Gianni) may follow a focused constituent in Italian: (29a) is from Rizzi (2001, his (5)). ${ }^{8}$ Argument fronting is barred in similar contexts in English (29b). ${ }^{9}$ One option to account for this different pattern is to postulate that CLLD arguments can be merged in the LP, thus putting them in line with initial circumstantial adjuncts (cf. Cinque 1990).
a. Credo che ieri,
QUESTO, a Gianni, $i$ tuoi amici think-1SG that yesterday THIS to Gianni the your friends avrebbero dovuto dirgli. have-cond-3PL must-PARTICIPLE say-him
'I believe that yesterday, THIS, to Gianni, your friends should have said to him'
b. $\quad *$ I think that to JOHN your book you should give.

\subsection{The movement derivation of temporal clauses}

As discussed in section 3.5., the unavailability of argument fronting in interrogative and relative clauses is ascribed to an intervention effect: in both relatives and interrogatives the argument blocks operator movement. It seems fairly natural to invoke the same account for the incompatibility of temporal clauses with argument fronting illustrated in section 3.2. Put succinctly here, temporal clauses would be derived by the leftward movement of an overt (when) or null temporal operator to the LP. This movement will be blocked by intervening fronted arguments in the same way that fronted arguments block the movement of the whoperator in interrogative clauses and in relative clauses. If the operator which derives the temporal clause also has the feature OP, argument fronting will give rise to an intervention effect. (30) is a schematic representation. That temporal clauses remain compatible with initial circumstantial adjuncts and with CLLD arguments follows from the movement account. See Haegeman (2010a).

$$
\begin{aligned}
& \text { *when this problem you are able to solve } \mathrm{t} \\
& \text { Q } \delta+Q \text { (topic) Q }
\end{aligned}
$$

The movement derivation of temporal clauses goes back at least to Geis (1970) and has repeatedly been appealed to. The following are but a sample of relevant references: Geis (1975), Enç (1987: 655), Larson (1987, 1990), Dubinsky and Williams (1995), Declerck (1997), Citko (2000), Demirdache and Uribe-Etxebarria (2004), Lipták (2005: 176), Stephens (2007), Lecarme (2008). The argument that has been invoked in support of this analysis is based on the ambiguity of examples such as (31), in which the temporal operator when may 
have 'high construal', with the interpretation 'I saw her at the time that she made that claim', and 'low construal', with the reading 'I saw her at the time of her presumed departure'. Larson (1987) offers the representations in $(31 \mathrm{a}, \mathrm{b})$ to distinguish the two readings. They crucially hinge on the movement derivation of the temporal clause:

(31) I saw Mary in New York when [IP she claimed [CP that [IP she would leave.]]] (Larson 1987)

a. I saw Mary in New York [CP when $_{\mathrm{i}}$ [IP $_{\text {she claimed [CP }}$ that [IP she would leave ] ] $\left.\left.t_{i}\right]\right]$

b. I saw Mary in New York [CP when $_{\mathrm{i}}$ IIP $_{\text {she claimed [CP }}$ that [IP she would leave $\left.\left.\left.t_{i}\right]\right]\right]$

As pointed out by Geis (1975) and many after him, it is predicted that the insertion of an element blocking movement can eliminate the low construal reading. This is shown in (32), where low construal would be derived by extraction from complex NP. See Johnson (1988) for additional evidence from intervention.

(32) I saw Mary in New York when she made [the claim that she would leave]. (Geis 1975, Larson 1987)

Demirdache and Uribe-Etxebarria (2004) propose that in temporal clauses the temporal operator is moved from SpecAspP. See Haegeman (2009, 2010a).

(33) a. When Zooey arrived...

B [рP $\varnothing[$ ZeitP $\varnothing[\mathrm{CP}$ when [те [AspP when ... $]]]]]$

\section{Conditionals as free relatives}

\subsection{The proposal}

Like temporal clauses, conditional clauses display the double asymmetry: they are compatible with CLLD in Romance, as well as with adjunct fronting, and they resist argument fronting. This double asymmetry will follow if conditional clauses are derived by movement of an operator to the LP. A movement analysis of conditional clauses has been proposed by, among others, Lycan (2001), Bhatt and Pancheva (2002, 2006), Arsenijević (2009), Lecarme (2008) and Tomaszewicz (2009). Bhatt and Pancheva $(2002,2006)$ say: "Our proposal that [conditional clauses] are interpreted as free relatives amounts to the claim that they are definite descriptions of possible worlds." (Bhatt and Pancheva 2006: 655). (34a) is derived by the leftward movement of a World operator, as in (34b):

(34) a. If John arrives late

b. $\quad\left[\mathrm{CP}_{\mathrm{OP}} \mathrm{CP}^{\circ}[\mathrm{John}\right.$ arrives late in $\left.\mathrm{w}]\right]$

If conditional clauses are derived by operator movement, the double asymmetry follows and is thus empirical support for the movement analysis.

\subsection{Additional support}




\subsubsection{Temporal clauses and conditional clauses}

The movement analysis for conditional clauses outlined above is based on a strong parallelism between such clauses and temporal clauses. Support for the parallelism between conditional clauses and temporal clauses comes from the observation that in many languages the prototypical 'conjunction' to introduce a temporal adverbial clause is isomorphic with that which introduces a conditional. For instance, the German conjunction wenn ('when', 'if') introduces both conditional (35a) and temporal (35b) clauses; the West Flemish (WF) conjunction oa ('when', 'if') serves to introduce both a temporal clause and a conditional clause (35c):
a. Wenn Steffi gewinnt, wird gefeiert.
if Steffi wins AUX-PASSIVE celebrate-PART
German
'If Steffi wins, there is a celebration.'
(Bhatt and Pancheva 2006: 657, their (7))
b. Wenn Steffi kommt, fangen wir an zu spielen. ${ }^{10}$ when Steffi arrives, begin we to play 'When Steffi arrives, we begin to play.'
c. Kgoan kommen oa-j doa zyt.
I will come if-you there are
WF
'I'll come if/when you are there'.

\subsubsection{Yes-no questions and conditionals}

Arsenijević's (2009) movement analysis of conditional clauses explores their parallelism with yes-no questions. Typically, the same conjunction is used to introduce embedded yes-no questions and conditional clauses (36a,b). Moreover, as shown in (36c,d), T-to-C movement, can derive both root yes-no questions and conditional clauses (see Bhatt and Pancheva (2006: 657-661) for discussion).

(36) a. I asked him if he had said that he would leave.

b. If he had said that he would leave...

c. Had he said that he would leave?

d. Had he said that he would leave....

If T-to-C movement is triggered by a checking relation between a head feature of $\mathrm{T}$ and an operator in the LP, then in both yes-no questions and in conditional clauses, the relevant operator must be non overt.

The Germanic Verb Second (V2) languages such as Dutch offer some support for postulating a null operator in the LP of root yes-no questions. In Dutch (37), direct yes-no questions constitute an apparent exception to the V2 constraint because the fronted verb seems to be the first constituent. If the LP of Dutch yes-no questions hosts an abstract operator (37b), the V2 constraint is maintained with the null operator occupying the initial position and the finite verb in second position. In addition, if the null operator is first merged in a TPinternal position, yes-no questions can be said to be derived by operator movement. ${ }^{11} \mathrm{By}$ analogy with root yes-no questions (37a), which display SAI and are arguably derived by the leftward movement of a null operator (37b), the movement hypothesis can be extended to the formally identical conditional clause in $(37 \mathrm{c})$ :

$$
\begin{aligned}
& \text { a. Had hij gezegd dat hij zou vertrekken? } \\
& \text { had he said that he would leave }
\end{aligned}
$$


'Had he told you he was leaving?'

b. $\quad\left[\mathrm{CP}\right.$ OP [vfin had ] [TP Subject ... t $\left.\left.\mathrm{t}_{\mathrm{op}}\right]\right]$

c. Had hij gezegd dat hij zou vertrekken, ik zou teruggebeld hebben. had he said that he would leave, I would back-called have 'Had he told me he was leaving, I would have called him back.'

We will assume that the conditional operator has the feature OP, which leads to intervention effects in the presence of a constituent in the LP with this feature. Assuming that fronted arguments have the feature $\mathrm{OP}$, the incompatibility of conditional clauses and MCP follows.

\subsection{Absence of low construal}

The objection that is often raised against the movement analysis of conditional clauses (see Geis 1985, Citko 2000, Bhatt and Pancheva 2002, 2006) is the fact that, unlike temporal clauses (31), conditional clauses do not allow low construal readings, as shown in English (38a) and (38b). A WF adverbial clause introduced by $o a$ has both a temporal ('when') and a conditional ('if') reading (39). With the former reading, both high and low construal are available, but with the conditional reading only high construal is available. Similar contrasts have been pointed out for German wenn (Bhatt and Pancheva 2002, 2006, but see Bayer 2000 for discussion), and for Polish jak (Citko 2000).

(38) a. I will leave if you say you will.

b. Had he said he would leave, I would have left.
Ge moet kommen
oan- $k$ jen zeggen da-j you must come
when-I you say
that-you must come
'You must come when/if I tell you to.'

The unavailability of the low construal reading in conditionals and its availability in temporal clauses were taken by Citko (2000) as direct evidence that conditional clauses are not derived by movement.

As has been noted by Geis (1970) and Larson (1987), the unavailability of longdistance construals is what distinguishes if clauses in English from when clauses. This difference is standardly attributed to the possibility to move the wh-pronoun when long-distance, which correlates with the long distance construal. In the case of if clauses, on the other hand, the option of long-distance movement does not exist, since if, being a complementizer, is base generated in $C^{\circ}$. (Citko 2000:6)

This is, as discussed, not the conclusion drawn by Bhatt and Pancheva $(2002,2006)$ and by Arsenijević (2009). To account for the unavailability of low construal, these authors propose that the moved World operator must locally bind its variable.

Arsenijević (2009) treats conditional clauses on a par with yes-no questions. Observe that like conditional if-clauses such questions display the double asymmetry:

(40) a. *Bill asked if such books John only reads at home. (Schachter 1992:108 (16a))

b. Mary asked me if, in St Louis, John could rent a house cheap. (Emonds 1976: 196 (100)

c. Je me demande si mon article, ils vont l'accepter pour le colloque. 
I me ask-1SG if my paper they go-3PL it accept for the conference 'I wonder if they'll accept my paper for the conference.'

The absence of low construal is a further parallelism: in the same way that conditionals resist low construal, yes-no questions do not allow for a low construal reading of the operator, ${ }^{12}$ as shown in (40d), in which the embedded yes-no question bears on the polarity of the clause introduced by if ('he said') and not on that of the clause embedded under said ('he would leave').

(40) d. I wonder if he said he would leave.

\section{SpOAs and conditional clauses}

If conditional clauses are derived by movement of an operator to the LP, the incompatibility with MCP, such as argument fronting, follows. The question arises whether this account also bears on the second property of conditional clauses addressed here, namely their incompatibility with SpOAs (4).

\subsection{The adverbial hierarchy (Cinque 1999)}

Based on the observed ordering restrictions in markers of modality and aspect, Cinque (1999) proposes that adverbials occupy specialised functional projections which constitute the clausal spine. SpOAs occupy the top layers of the clausal spine:

(41) $\quad$ MoodP $\mathrm{P}_{\text {speech act }}>\mathrm{MoodP}_{\text {evaluative }}>\mathrm{MoodP}_{\text {evidential }}>\mathrm{ModP}_{\text {epistemic }}>\mathrm{TP}(\mathrm{Past})>\mathrm{TP}$ (Future) $>\operatorname{MoodP}_{\text {irrealis }}>\mathrm{ModP}_{\text {alethic }}>\mathrm{AspP}_{\text {habitual }}>\mathrm{AspP}_{\text {repetitive }}>$ $\mathrm{AspP}_{\text {frequentative }}>\mathrm{ModP}_{\text {volitional }}>$ etc.

Cinque's proposal allows an elegant account for the ordering restrictions observed by Koster (1978) for the Dutch adverbs in (42): the evaluative adverb helaas ('unfortunately') precedes the epistemic adverb waaschijnlijk ('probably') (42a), the inverted order is ungrammatical (42b). When an adverb is moved to clause-initial position, it is the evaluative adverb helaas which will be initial (42c,d). To achieve the order in (42d), the adverb waarschijnlijk would have to cross helaas. Assuming that the SpOAs share a relevant property, a higher adverb will block the lower adverb from crossing it.
a. Hij is helaas waarschijnlijk ziek. he is unfortunately probably ill 'Unfortunately, he's probably ill.'
b. $\quad * H i j$ is waarschijnlijk helaas ziek.
c. Helaas is hij waarschijnlijk ziek.
d. *Waarschijnlijk is hij helaas ziek.

(Koster 1978: 205-209)

Time and place adjuncts are not subject to the strict ordering constraints with respect to the modal adverbs. Thus, for instance, the time specification vandaag ('today') seems to be freely positioned with respect to SpOAs. It also does not intervene in the leftward movement of the epistemic or evaluative modal adverb.

a. Hij is (vandaag) helaas (vandaag) waarschijnlijk (vandaag) ziek. 

he is (today) unfortunately (today) probably (today) sick
'Unfortunately, today he's probably ill.'
b. Waarschijnlijk/Helaas is hij vandaag ziek. probably/unfortunately is he today sick
'Unfortunately, today he's probably ill.'

Though a full understanding of what sets apart temporal adjuncts such as vandaag from modal adverbs such as waarschijnlijk and helaas is beyond the scope of this paper, it is clear that their syntactic properties must differ. (For proposals to differentiate circumstantial modifiers and modal adverbials, see, among others, Alexiadou (1997), Laenzlinger (1996: 107), Cinque (1999: 29, 2004), Hinterhölzl (2009) etc.) We will briefly illustrate a few differences here. As also pointed out in Cinque (1999), modal adverbs cannot undergo whmovement. Whereas the epistemic adjective probable can be pied-piped to the LP by the associated degree adverb how with a $w h$-feature, this is not possible for its adverbial counterpart (44a). On the other hand, temporal -ly adverbs such as recently can be pied piped and $w$ h-moved (44b). Similarly, clefting is not available for SpOAs (45a), but temporal adjuncts can be clefted (45b). French temporal adjuncts may license stylistic inversion, a process whereby the lexical subject remains in a lower position in the clause (46a); modal adverbs do not license this pattern (46b).

(44) a. *How probably/likely will he arrive late? (cf. 'How probable/likely is it that...')

b. How recently have you done an energy audit of your site? (www.chemical processing.com/ articles/ 2008/131.html - 59k)

(45) a. *It is probably/obviously/without any doubt that he left.

b. It was initially that people had the Shadow confused with the Droid2 but bill and Winston straightened it out for us.( http://rim.howardforums.com /showthread.php?t=1638604)

c. It is only recently that I have found out. ${ }^{13}$

(46) a. et soudain surgirent six hommes noirs and suddenly emerge-PAST-3PL six black men 'and all of a sudden, six black men emerged'

b. *Probablement se noueront des relations... probably se form-FUT-3PL relationships

Based on such differences, Cinque concludes that the relevant temporal and locative adjuncts are not specifiers within the hierarchy that he establishes. Rather they are specifiers in higher VP shells (cf. Cinque 1999: 29, also: pp. 15-16 and 28-30). The distinction requires further research, but we take that the data above are sufficient evidence for it at this point. See also Schweikert (2005) for a proposal.

\subsection{Locating the world operator: IrrealisP}

For their movement derivation of conditional clauses, Bhatt and Pancheva $(2002,2006)$ provided representation (34), repeated for convenience in (47):

(47) a. If John arrives late

b. $\quad\left[\mathrm{CP} \mathrm{OP}_{\mathrm{w}} \mathrm{C}^{\circ}[\right.$ John arrives late in $\left.\mathrm{w}]\right]$ 
However, (47b) does not represent unequivocally where $\mathrm{OP}_{\mathrm{w}}$ is first merged. On an antisymmetric view of clause structure without right adjunction, one might infer from the sentence-final position of the variable (in $w$ ) in (47b) that the operator is first merged in a VPinternal position. If this were the case, whenever extraction from VP is blocked, the movement required to derive conditional clauses should become unavailable. One relevant pattern to consider in this light is a type of VP anaphora with non-finite $d o$, referred to in the literature as 'British do' (Johnson 2001, Haddican 2006, Aelbrecht 2009, 2010). Crucial for the present purpose is the observation that British do is incompatible with extraction, as shown in (48a). In this light, consider the attested (48b), in which the conditional antecedent contains 'British $d o$ '. If movement has taken place in the conditional clause in (48b) -the hypothesis adopted here - it cannot have been launched from within VP, since British do is incompatible with extraction from VP, and hence the extraction must have targeted a higher position which is not affected by whatever process derives 'British $d o$ ' (say substitution as in Haddican (2006) or VP ellipsis as in Aelbrecht (2009, 2010).
a. $\quad$ *Although I don't know who Thomas will visit I know who Aga will do. (Aelbrecht 2009: 212, her (83a))
b. Have you ever taken antidepressants?
No, and if I had done, I wouldn't tell you. (Observer magazine, 13.9.9 page $7 \mathrm{col} 1$ )

Following Bhatt and Pancheva (2006), Arsenijević (2009) locates the world operator which moves in conditional clauses in a projection 'WorldP', whose values are [actual] or [possible]. Reinterpreted in terms of the Cinque hierarchy, WorldP seems closest to IrrealisP, the projection that encodes values such as [real]/[unreal], i.e. "when the speaker doesn't know if the proposition is true" (Cinque 1999: 88). Our hypothesis will be that the operator that moves to the LP in conditional clause originates in IrrealisP (Haegeman 2007, 2010b). Schematically conditionals are derived as in (49):

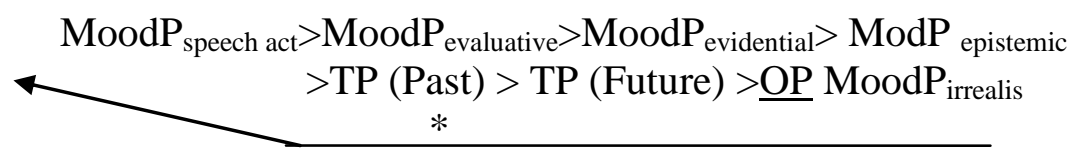

We will not try to label the landing site of the operator here. Let us assume that it moves to the specifier of the projection that is involved in clause typing, and which Rizzi (1997) labels as ForceP.

The Irrealis operator that is moved to the LP to derive conditional clauses belongs to the class of high modal markers in Cinque's approach. It will share crucial features with these modal markers and if it moves, any modal marker above IrrealisP will give rise to intervention effects. (See also Agouraki (1999: 30) for evidence that modals can be interveners for operator movement.) It thus directly follows from this hypothesis that conditional antecedents are incompatible with speech act adverbials, evaluative adverbials, evidential adverbials and epistemic adverbials.

Suggestive support for the proposal that the Irrealis operator is implicated in the derivation of conditional clauses comes from Polish. Tomascewicz (2009) discusses the patterns in (50): the Irrealis particle by appears on the finite verb in (50a). As can be seen, the same particle is attached to the conditional conjunction (50b,c). See also Migdalski (2006). 


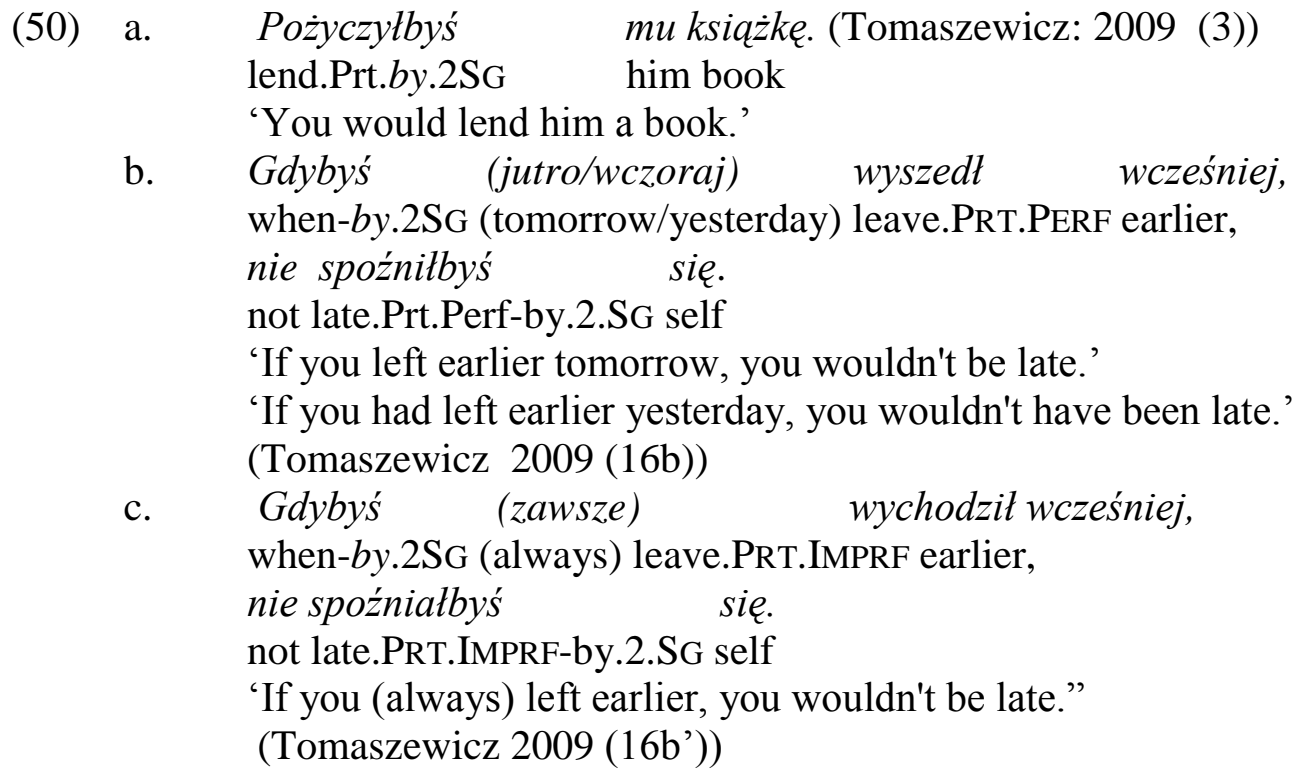

Since the conditional operator is merged in IrrealisP, it follows that lower modal markers remain available in conditional clauses. (51) illustrates expressions of ability (can) and of volition (deliberately) in the conditional antecedent. See Cinque (1999: 203, note 33) for adverbials expressing these modalities and also Haegeman (to appear) for additional data from WF.

(51) a. I will call you if I can locate a phone.

b. If he deliberately ignores these warnings, he'll be arrested.

\subsection{Conditionals lack low construal: A problem becomes an argument in favour}

The similarity between SpOAs and the Irrealis operator that derives conditionals can also be invoked in order to account for the lack of low construal readings for conditionals. (52) shows that in general SpOAs cannot undergo long movement (cf. Cinque 1999: 18): in these examples the modal adverb in the higher clause cannot be construed as modifying the lower clause. Thus, for instance, probably in (52a) cannot be seen as related to the embedded clause ('that Mary will come'). Put differently, (52a) does not have the interpretation of (52b). The same holds for (52c), which does not have the same interpretation as (52d).

(52) a. Probably he thinks that Mary will come.

b He thinks that Mary probably will come

c. Obviously he thinks that Mary will come.

d. He thinks that Mary obviously will come.

The observed restriction on long movement for SpOAs now provides a way of accounting for the absence of low construal in conditionals. If the operator that derives conditionals belongs to the class of high modals, i.e. SpOAs, then whatever property excludes long movement of high modals/SpOAs can be invoked to exclude long movement of the Irrealis operator that derives conditional clauses.

Note in passing that absence of long movement also sets apart SpOAs from circumstantial adjuncts, which are compatible with long movement as already shown in (25). 


\subsection{Peripheral conditional clauses}

As we have observed in section 2.2. (example (5)), peripheral conditional clauses are compatible with MCP and with high modals. This means that in these conditionals there must be no intervention effects of the type found with central conditionals. To account for this one might adopt the view that in such conditional clauses the conjunction if has grammaticalised into becoming a mere connector which is merged in Force, and which does not lead to operator movement, or alternatively, one might assume that if is in Force and does trigger some form of operator movement but that this takes place in the high domain of the LP and does not interfere with the fronting operations in the LP. One way of thinking about this is to relate these conditional clauses to 'conditional speech acts' or 'conditional assertions', and to postulate that there is a syntactic representation of the speech event. See Hill (2006, 2007a,b). For reasons of space we cannot elaborate further on these hypotheses here.

\subsection{Non asserted that clauses}

In the literature the discussion of the distribution of MCP has tended to focus on their restricted distribution in embedded that clauses (Hooper and Thompson 1973, Emonds 1970, 1976, Emonds 2004). Typically, complements of factive verbs are taken to be incompatible with MCP:

(53) a. (\%)*John regrets [that this book Mary read]. (Maki et al., 1999: 3, their $(2 \mathrm{c}))$

b. $\quad *$ I regret [that Mary, my antics upset as much as they did]. (Alrenga 2005: 179 (16b))

c. *Mary realizes [that this book, John read]. (Hegarty 1991: 52, n. 19, his (iii))

d. *John regretted that Gone with the Wind, we went to see. (Watanabe (1993: 525))

At the same time, such complement clauses are compatible with locally construed adjuncts (54) and with CLLD (55).

(54) a. John regrets that last week Mary did not turn up for the lecture.

b. $\quad$... so it's not surprising that throughout history we've taken some bad turns.

(The monks of New Skete. 1999. In the spirit of happiness. Little, Brown, and Company. 181.) (Santorini 2001)

(55) Jean regrette que son texte tu ne l'aies pas encore lu. Jean regret-3SG that his text you ne it have-SUBJ-2SG not yet read-PART. 'Jean regrets that you haven't read his text yet.'

So once again finite that-clauses display the double asymmetry which we have taken to be diagnostic of intervention. (53)-(55) lead to the conclusion that that clauses resisting MCP are derived by operator movement. Various questions arise at this point, including the nature of the moved operator and its landing site. Unfortunately, for reasons of space we cannot explore 
this point here but we refer to Haegeman (in preparation) and to Haegeman and Ürögdi (in preparation) for proposals. Let us just point out here that there is cross-linguistic support for a movement derivation of complement clauses of factive verbs (Aboh 2004, Krapova 2008, 2010).

\section{Emphatic polarity as an MCP}

In the discussion above we have argued that the unavailability of argument fronting in English conditional clauses follows from the proposed movement derivation. The $\mathrm{Q}$ feature associated, by hypothesis, with fronted arguments in English will block the movement of the Irrealis operator (itself also associated with OP). We will assume that the constituents which are fronted in the case of locative inversion (2a), preposing around be (2b), and VP topicalization ( $2 \mathrm{c}$ ) also bear the $\mathrm{Q}$ feature and hence also lead to intervention effects. Their incompatibility with conditional clauses then follows from the same analysis. For reasons of space we cannot elaborate this proposal further here.

We do not wish to imply that all MCP that have been discussed in the literature are amenable to the intervention account. In particular, it is not clear at this point whether an intervention account can be invoked for the restrictions on the distribution of Verb Second, which patterns to some extent with the MCP illustrated above. This must be subject to further research, especially given the important degree of cross-linguistic variation in languages allowing embedded V2 (see Bentzen et al. (2007a, 2007b) and Wiklund (2009) among others).

Adopting the account developed here, adverbial clauses may be used as a diagnostic for detecting intervention effects, i.e. for detecting the presence of operators in the LP. For instance, a number of recent papers have explored the hypothesis that expressions of emphatic affirmation/denial may implicate an operator in the left-peripheral SpecFocP. The movement account of conditional clauses which we elaborate here correctly predicts that these expressions of emphatic polarity are banned from the conditional clauses: the focus operator required for the expression of emphatic affirmation/denial will interfere with the movement of the Irrealis operator for the derivation of the conditional clause. We illustrate some such patterns in sections 6.1.-6.3.

\subsection{Emphatic polarity bien/si in the Spanish left periphery (Hernanz 2007a,b)}

Hernanz (2007a,b) discusses the marker of emphatic affirmation bien in Spanish (56a). She proposes that bien is a wh-operator merged in SpecPolP and moved to SpecFocP. (Hernanz 2007b: 131-139). (56a) has the representation in (56b):

(56) a. Pepito bien ha comido pasta. (Hernanz 2007b : 113 ) Pepito bien have-3SG eat-PART pasta 'Pepito HAS eaten pasta.'

b. [ForceP [TopicP Pepito [FocusP $_{\text {bien }}$ [ $\left[\right.$ PolP $\left.\left.\left._{\mathrm{i}}\left[\mathrm{IIP}_{\mathrm{j}} \ldots\right]\right]\right]\right]$

If conditional clauses are derived by leftward movement of an Irrealis operator, we correctly predict their incompatibility with emphatic bien: the very presence of the operator in SpecFocP will block the movement.

$$
\begin{aligned}
& \text { c. Si Pepe (*bien) acaba a tiempo su tesis, ya te lo haré saber. }{ }^{14} \\
& \text { if Pepe (*well) finish-3SG on time his thesis, I you it let-FUT-1sG know } \\
& \text { 'If Pepe finishes his thesis on time, I'll let you know.' }
\end{aligned}
$$




\subsection{Sentence-final emphatic negation in Italian (Zanuttini 1997, Poletto 2008, 2009)}

In the Veneto dialect (Poletto 2008, Zanuttini 1997) a sentence-final stressed particle $N O$ ('not') serves to express emphatic negation.

$$
\begin{aligned}
& \text { a. No ghe so ndà NO. } \\
& \text { Not there be-3PL go-PART NOT } \\
& \text { 'I did not go there' (Poletto 2009: 6, her (9)) }
\end{aligned}
$$

To account for the final position of $N O$ in (57a), Poletto (2009:6) proposes:

According to this analysis, NO is always moved from within the NegP where it originates [note omitted, d\&h] to a Focus position, which, following standard assumptions on the structure of the clause in Italian is located low in the CP area. When NO is in first position, there is no IP fronting. When NO is in sentence final position, this is the result of a movement of the whole IP to a position, GroundP, which is located in the Topic field, higher than Focus (again following standard assumptions on the CP layer) [note omitted $d \& h$ ]

$$
\begin{aligned}
& \text { b. [SpecGroundP [IP no ghe so ndà] [Ground }{ }^{\circ} \text { [CPFocus NO] } \\
& \text { [FinP [IP no ghe so ndà]]] [Fin' [IP no ghe so ndì]]] } \\
& \text { (Poletto 2009:6, her (13)) }
\end{aligned}
$$

Predictably, sentence-final $N O$ is incompatible with conditional clauses (Poletto 2009: 9, her (37b)). In (57c) the movement triggered by $N O$ blocks the operator movement required to derive the conditional clause:

(57) c. Dovrebbe finire il lavoro per stasera. must-COND-3SG finish the work for tonight. 'He ought to finish his work by tonight.'

*Se non lo finisce NO, lo faccio io. if non it finish-3SG NO it do-1SG I 'If he does not finish it, I'll do it myself.' (C. Poletto, p.c. 22.10.08)

\subsection{Latin quidem}

Danckaert (2009) discusses the distribution of the Latin particle quidem ('indeed'), which expresses emphatic polarity. Based on a corpus of prose texts (approx. 1.500 .000 words) Danckaert shows that quidem does not occur in central adverbial clauses and that it is found in peripheral adverbial clauses, including peripheral conditionals. (58) is from his presentation (Danckaert 2009: 5, his (18)):

(58) Bono praesidio munitur existimatio tua, by good protection is.guarded reputation your si quidem in Aproni constituitur diligentia atque auctoritate. if PRT in A.'s is.put care.ABL and influence.ABL 'Your reputation is well protected, if indeed it depends on Apronius' care and influence'. (= Cic. Ver. II.3.154) 


\subsection{The expression of emphatic polarity as a $M C P$}

On the basis of the data discussed in the preceding sections we seem to have uncovered another set of data that can potentially be categorized as MCP and which have not so far been treated as such: all the expressions of emphatic assertion and emphatic denial discussed so far are excluded from conditional clauses.

However, not all expressions of emphatic polarity have MCP status, since a subset of such expressions are compatible with conditional clauses. ${ }^{15}$ English emphatic do expresses polarity emphasis (cf. Laka 1990, Duffield 2007) but it remains available in conditional clauses (59a). Similarly, stressed auxiliaries as a way of emphasizing polarity are compatible with conditional clauses $(59 \mathrm{~b})$.

(59) a. If he DOES win, I'll be the first to congratulate him. b. If he HAS finished the thesis by the end of this year, I'll be surprised.

With respect to the expression of emphatic assertion through 'auxiliary focus', Hyman and Watters (1984) show that this leads to "focus or emphasis ... on the validity (truth value) of the proposition" (Hyman and Watters 1984: 234). They observe that while in some languages auxiliary focus is available in all clause types, in most languages it is restricted to main clause types or embedded clause types that can be assimilated to main clauses (1984:256). They say that in many languages "one or more types of subordinate clauses require [-focus] forms [of the auxiliary, $d \& h]$ ". In such languages, they propose, "focus marking is grammatically, not pragmatically, controlled" (1984: 256). Among clause types that resist the focussed auxiliary they list relative clauses, temporal clauses, antecedent if clauses.

One essential difference between expressions of emphatic polarity that are incompatible with conditional clauses discussed in sections 6.1-6.3 and those that are compatible with them (6.4) is the fact that the former are syntactically realized in the LP whereas the latter are realized TP-internally. The question then arises how to analyse instances of polarity emphasis that are manifestly not MCP. One option that one could explore is to assume that they too involve a focus projection, but that the relevant projection is NOT located in the LP but rather that it is a low focus projection in the sense of Belletti (2001, 2004). On this assumption, a unified analysis of polarity focus remains available, with both the expressions of polarity emphasis that are MCP and those that are not involving an operator in FocP, but while for the first type FocP in the LP is implicated, for the latter it is the lower FocP. The contrast between expressions of polarity emphasis that lead to intervention effects and those that do not is reminiscent of the difference between focalization qua movement to the LP, which is an MCP, and focalization in situ, which is not, as illustrated in (7). We intend to return to this point in future research.

The question also arises, if those manifestations of auxiliary focus discussed by Hyman and Watters which pattern with MCP also implicate movement to the LP. For reasons of space we cannot go into this point here.

\section{Conclusion}

The paper explores and elaborates the hypothesis that conditional clauses are derived by movement of an operator to the LP. A cartographic approach is adopted and it is argued that the moved operator that derives conditional clauses originates in the projection Mood $_{\text {irrealis }}$ (Cinque 1999). The movement derivation of conditional clauses accounts for both (i) the unavailability of Main Clause Phenomena, and (ii) the unavailability of SpOAs (Ernst 2009) in conditionals in terms of locality conditions on movement. 
The final part of the paper shows that a subset of the expressions of emphatic polarity pattern with MCP and are incompatible with conditional/temporal adverbial clauses, while others are not restricted to root domains. It is shown that this can be made to follow from the intervention account: those expressions of emphatic polarity which are incompatible with conditional clauses implicate the LP of the clause, while those that are compatible with conditional clauses are encoded TP-internally.

\section{References}

Aboh, E. O. 2004. The Morphosyntax of Complement-Head Sequences. Clause Structure and Word Order Patterns in Kwa. New York and Oxford: Oxford University Press.

Aelbrecht, L. 2009. You Have the Right to Remain Silent. The Syntactic Licensing of Ellipsis. PhD. Dissertation, HUBrussel.

Aelbrecht, Lobke. 2010. The Syntactic Licensing of Ellipsis. Amsterdam: John Benjamins.

Agouraki, Y. 1999. Propositional operators. In Studies in Greek Syntax. A. Alexiadou, G. Horrocks and M. Stavrou (eds.), 23-44. Dordrecht: Kluwer.

Alexiadou, A. 1997. Adverb Placement. A Study in Antisymmetric Syntax. Amsterdam: John Benjamins.

Alrenga, P. 2005. A sentential subject asymmetry in English and its implications for complement selection. Syntax 8: 175-207.

Anagnostopoulou, E. 1994. Clitic dependencies in Modern Greek. PhD. Diss, University of Salzburg.

Arsenijević, B. 2009. Correlatives as types of conditional. In Correlatives Crosslinguistically, Lipták, (ed.), 131-156. Amsterdam: John Benjamins.

Barbiers, S. 2007. On the periphery of imperative and declarative clauses in Dutch and German. In Imperative Clauses in Generative Grammar, W. van der Wurff (ed.), 95-112. Amsterdam: John Benjamins.

Bayer, J. 2000. Basic order. In Von der Philologie zur Grammatiktheorie. J. Bayer and C. Römer, (eds.), 45-62. Tübingen: Niemeyer.

Bayer, J. 2001. Asymmetry in emphatic topicalization. In Audiatur Vox Sapientiae. C. Féry, W. Sternefeld (eds.). Studia Grammatica 52: 15-47.

Belletti, A. 2001 Inversion as focalisation. In Subject inversion in Romance and the theory of Universal Grammar. A. Hulk and J.-Y. Pollock (eds.), 60-90. Oxford and New York: Oxford University Press.

Belletti, A. 2004. Aspects of the low IP area. In The Structure of CP and IP, L. Rizzi (ed.), 16-51. Oxford and New York: Oxford University Press.

Belletti, A. 2009. Structures and Strategies. New York: Routledge.

Benincà, P. and C. Poletto. 2004. Topic, Focus and V2: defining the CP sublayers.' In The Structure of CP and IP. L. Rizzi (ed.), 52-75. New York and Oxford: Oxford University Press.

Bentzen, K. Hrafnbjargarson, G.H., Hróarsdottir, P., and Wiklund, A.-L. 2007a. The Troms $\varnothing$ guide to the Force behind V2. Working Papers in Scandinavian Syntax 79: 99-118.

Bentzen, K., Hrafn Hrafnbjargarson, G., Hróarsdóttir, P., and Wiklund, A.-L. 2007b. Extracting from V2. Working Papers in Scandinavian Syntax 79: 119-128.

Bhatt, R. and Pancheva, R. 2002. A cross-constructional analysis of if clauses. Paper presented at the Syntax Seminar: interface in the CP domain, Zentrum für Allgemeine Sprachwissenschaft, Berlin, March 9, 2002.

Bhatt, R. and Pancheva, R. 2006. Conditionals. In The Blackwell Companion to Syntax, M. Everaert and H.van Riemsdijk (eds.), Vol 1: 638-687. Boston and Oxford: Blackwell. 
Bianchi, V. and M. Frascarelli. 2009. Is Topic a root phenomenon? Paper presented at the conference on Root Phenomena, Zentrum für Allgemeine Sprachwissenschaft, Berlin, September 2009. (Lingbuzz).

Bocci, G., 2007. Criterial positions and left periphery in Italian. Evidence for the syntactic encoding of contrastive focus. Nanzan Linguistics, Special Issue. 3.

Boeckx, C. and Y. Jeong. 2004. The fine structure of intervention in syntax. In Issues in Current Linguistic Theory: A Festschrift for Hong Bae Lee, C. Kwon and W. Lee (eds.), 83-116. Seoul: Kyungchin.

Bouma, G., Malouf, R. and Sag, I. 2001. Satisfying constraints on extraction and adjunction. Natural Language and Linguistic Theory 19: 1-65.

Browning, M. 1996. CP recursion and that-t effects. Linguistic Inquiry 27: 237-256.

Cardinaletti, A. 2008. On a (wh-) moved Topic in Italian, compared to Germanic. Paper presented at the Comparative Germanic Syntax Workshop, Stuttgart.

Cinque, G. 1990. Types of $A^{\prime}$-dependencies. Cambridge: MIT Press.

Cinque, G. 1999. Adverbs and Functional Heads. Oxford and New York: Oxford University Press.

Cinque, G. 2004. Complement and adverbial PPs: implications for clause structure. In Restructuring and functional heads, 145-165. Oxford and New York: Oxford University Press.

Citko, B. 2000. On the syntax and semantics of Polish adjunct clauses. Journal of Slavic Linguistics 8: 1-38

Cruschina, S. 2010. Syntactic extraposition and clitic resumption in Italian. Lingua 120: 5073.

Danckaert, L. 2009. Polarity Focus and the Latin particle quidem in adverbial clauses. Paper presented at the conference on Root Phenomena, Zentrum für Allgemeine Sprachwissenschaft, Berlin, September 2009.

Declerck, R. and Depraetere, I. 1995. The double system of Tense forms referring to future time in English. Journal of Semantics 12: 169-310.

Declerck, R. 1997. When-clauses and Temporal Structure. London: Routledge.

Delfitto, D. 2002. On the semantics of pronominal clitics and some of its consequences. Catalan Journal of Linguistics 1: 41-69.

Demirdache, H. and Uribe-Etxebarria, M. 2004. The syntax of time adverbs. In The Syntax of Time, J. Guéron and J. Lecarme (eds.), 143-180. Boston: MIT press,.

Dikken, M. den 2006. Either float and the syntax of co-or-dination. Natural Language and Linguistic Theory 24: 689-749.

Duffield, N. 2007. Aspects of Vietnamese clausal structure: separating tense from assertion. Linguistics 45: 765-814.

Emonds, J. 1970. Root and structure preserving transformations. PhD dissertation, Cambridge MIT.

Emonds, J. 1976. A Transformational Approach to English Syntax. New York: Academic Press.

Emonds, J. 2004. Unspecified categories as the key to root constructions. In Peripheries, D. Adger, C. De Cat and G. Tsoulas (eds.), 75-121. Dordrecht: Kluwer.

Enç, M. 1987. Anchoring conditions for Tense. Linguistic Inquiry 18: 633-657.

Endo, Y. 2007. Locality and Information Structure. Amsterdam: John Benjamins.

Ernst, T. 2002. The Syntax of Adjuncts. Cambridge: Cambridge University Press.

Ernst, T. 2007. On the role of semantics in a theory of adverb syntax. Lingua 117: 1008-1033.

Ernst, T. 2009. Speaker-oriented adverbs. Natural Language and Linguistic Theory 27: 497544. 
Frascarelli, M. and Hinterhölzl, R., 2007. Types of topics in German and Italian. In On Information Structure, Meaning and Form, S. Winkler and K. Schwabe (eds.), 87-116. Amsterdam: John Benjamins.

Garzonio, J. 2008. Dislocazioni a sinistra e clitici di ripresa obbligatori. Annali Online di Ferrara, vol $2: 1-19$.

Geis, M. 1970. Adverbial Subordinate Clauses in English. Ph.D. Dissertation, Cambridge: MIT.

Geis, M. 1975. English time and place adverbials. Working Papers in Linguistics 18, Ohio State University. 1-11.

Geis, M. 1985. The syntax of conditional sentences. In Studies in Generalised Phrase Structure Grammar, M. Geis (ed.), 130-159. Columbus, OH: Department of Linguistics, OSU.

Grohmann, K. 2005. Top issues in Questions: Topics - Topicalization - Topicalizability. In Wh-movement: Moving on. L. Cheng and N. Corver (eds.), 249-288. Cambridge: MIT Press.

Haddican, W. 2006. The structural deficiency of verbal pro-forms. Linguistic Inquiry 37: 539-540.

Haegeman, L. 2003a. Conditional clauses: external and internal syntax. Mind and Language 18: 317-339.

Haegeman, L. 2003b. Notes on long adverbial fronting in English and the left periphery. Linguistic Inquiry 34: 640-649.

Haegeman, L. 2006a. Argument fronting in English, Romance CLLD and the Left Periphery. In Negation, Tense and Clausal Architecture: Cross-linguistic Investigations, $\mathrm{R}$. Zanuttini, H. Campos, E. Herburger, and P. Portner (eds.), 27-52. Georgetown University Press.

Haegeman, L. 2006b. Conditionals, factives and the left periphery. Lingua 116: 1651-1669. Haegeman, L. 2006c. Clitic climbing and the dual status of sembrare. Linguistic Inquiry 37: 484-501.

Haegeman, L. 2007. Operator movement and topicalization in adverbial clauses. Folia Linguistica 18: 485-502.

Haegeman, L. 2009. The movement analysis of temporal adverbial clauses. English Language and Linguistics 13: 385-408.

Haegeman, L. 2010a. The internal syntax of adverbial clauses. In Exploring the Left Periphery, K. Grohmann and I. Tsimpli (eds.). Lingua 120: 628-648.

Haegeman, L. 2010b. The movement derivation of conditionals. Linguistic Inquiry 41,595621.

Haegeman, L. (in preparation) Locality and the distribution of main clause phenomena. Ms. Ghent University.

Haegeman, L. and B. Ürögdi (in preparation) Referential CPs and DPs: An operator movement account.

Hegarty, Michael. 1992. Familiar complements and their complementizers: On some determinants of A'- locality. Unpublished manuscript: University of Pennsylvania.

Heinämäkki, O., 1978. Semantics of English temporal connectives. PhD. dissertation, Department of Linguistics, University of Helsinki. Reproduced by Indiana University Linguistics Club.

Heycock, C. 2006. Embedded root phenomena. In The Blackwell Companion to Syntax. M. Everaert and H. van Riemsdijk (eds.), Vol II: 174-209. Boston and Oxford: Blackwell. Hill, V. 2006. Stylistic inversion in Romanian. Studia Linguistica 60: 156-180.

Hill, V. 2007a. Romanian adverbs and the pragmatic field. The Linguistic Review 24: 61-86. Hill, V. 2007b. Vocatives and the pragmatics-syntax interface. Lingua 117: 2077-2105. 
Hinterhölzl, R. 2009. A phase based comparative approach to modification and word order in Germanic. Syntax 12: 242-284.

Hooper, J. and Thompson, S. 1973. On the applicability of Root Transformations. Linguistic Inquiry 4: 465-97.

Hrafnbjargarson, G. H. 2008. Liberalizing modals and floating clause boundaries. University of Tromsø (Lingbuzz).

Hukari, T. E., and Levine, R. D. 1995. Adjunct extraction. Journal of Linguistics 31: 195-226.

Hyman, L. M. and Watters, J.R. 1984. Auxiliary focus. Studies in African Linguistics 15: 23373.

Ingham, R. 2008. Negative co-ordination in Middle English. Paper presented at the workshop on Continuity and Change in Grammar. University of Cambridge, 18-20 March 2008

Johnson, K. 1988. Clausal gerunds, the ECP and government. Linguistic Inquiry 19: 583-609.

Johnson, K. 2001. What VP ellipsis can do and what it can't, but not why. In The Handbook of Contemporary Syntactic Theory, M. Baltin and C. Collins (eds.), 439-479. Boston and Oxford: Blackwell.

Kandybowicz, (2008) The Grammar of Repetition. Amsterdam: John Benjamins.

Kearns, J. T. 2006. Conditional assertion, denial, and supposition as illocutionary acts. Linguistics and Philosophy 29: 455-485.

Koster, J. 1978. Locality Principles in Syntax. Foris: Dordrecht.

Krapova I. 2008. Bulgarian relative clauses with the invariant complementiser deto. Paper presented at the Third Annual Meeting of the Slavic Linguistics Society. The Ohio state University, Columbus, Ohio, USA, June 10-12, 2008.

Krapova, I. 2010. Bulgarian relative and factive clauses with the invariant complementizer deto 'that'. Lingua 120: 1240-1272.

Krifka, M. 2001. Quantifying into question acts. Natural Language Semantics 9: 1-40.

Laenzlinger, C. 1996. Adverb syntax and phrase structure. In Configurations. Essays on Structure and Interpretation, A.-M. Di Sciullo (ed.), 99-128. Somerville: Cascadilla Press.

Laka, I. 1990. Negation in Syntax: On the Nature of Functional Categories and Projections. $\mathrm{PhD}$ dissertation, Cambridge MIT.

Larson, R. 1987. 'Missing prepositions' and the analysis of English free relative clauses. Linguistic Inquiry 18: 239-266.

Larson, R. 1990. Extraction and multiple selection in PP. The Linguistic Review 7: 169-182.

Larson, R. 1985. On the syntax of disjunction scope. Natural Language and Linguistic Theory 3: 217-164.

Larson, R. K. and Sawada, M. 2004. Presupposition and root transforms in adjunct clauses. NELS 34:517-528

Lecarme, J. 2008. Tense and modality in nominals. In Time and Modality, J. Guéron and J. Lecarme (eds.), 195-225. Dordrecht: Springer.

Lipták, A. 2005. Relativization strategies in temporal adjunct clauses. Linguistic Variation Yearbook 5. Amsterdam: John Benjamins. 133-185.

Lipták, A.(ed.). 2009. Correlatives Cross-linguistically. Amsterdam: John Benjamins.

Lycan, G. 2001. The syntax of conditional sentences. In Real Conditionals. Oxford: Clarendon Press. 1-15.

Maki, H., Kaiser, L. and Ochi, M. 1999. Embedded topicalization in English and Japanese. Lingua 109: 1-14.

Martins, A.-M. 2006. Emphatic verb reduplication in European Portuguese.. Paper presented at Workshop on Syntactic Doubling, Amsterdam, March 2006.

http://www.meertens.knaw.nl/projecten/edisyn/Online_proceedings/Paper_Martins.pdf 
Migdalski, K. 2006. The Syntax of Compound Tenses in Slavic. Utrecht: LOT dissertations 130.

Nilsen, $\varnothing .2004$. Domains for adverbs. In Adverbs across Frameworks. A. Alexiadou (ed.), Lingua 114: 809-847.

Palmer, F.R., 1990. Modality and English Modals. London: Longman.

Postal, P., and Ross, J.R. 1971. A problem of adverb preposing. Linguistic Inquiry 1: 145-6.

Riemsdijk, H. van and Everaert, M. (eds.). 2006. The Blackwell Companion to Syntax. Boston and Oxford: Blackwell.

Rizzi, L. 1990. Relativized Minimality. Cambridge: MIT Press.

Rizzi, L. 1997. The fine structure of the left periphery. In Elements of Grammar, L. Haegeman (ed.), 281-337. Kluwer: Dordrecht.

Rizzi, L. 2001. On the position 'Int(errogative)' in the left periphery of the clause. In Current studies in Italian syntax: essays offered to Lorenzo Renzi. G. Cinque \& G.Salvi (eds.), 287296). Amsterdam: Elsevier.

Rizzi, L. 2004. Locality and left periphery. In Structures and Beyond. The Cartography of Syntactic Structures 3, A. Belletti, (ed.), vol. 3, 223-251, New York and Oxford: Oxford University Press.

Roberts, I. and Roussou, A. 2002. The Extended Projection Principle as a condition on tense dependency. In Subjects, Expletives and the IPP, P. Svenonius (ed.), 125-155. New York and Oxford: Oxford University Press.

Samek-Lodovici, V. 2007. Asymmetries between pre- and post-focus left-peripheral topics in Italian. LAGB meeting, King's College London.

Santorini, B. 2001. (Un?)expected main clause phenomena. http://www.ling.upenn.edu/ beatrice/ examples/mcp-contents.html

Schachter, P. 1992. Comments on Bresnan and Kanerva's "Locative inversion in Chichewa: a case study of factorization in grammar". In Syntax and semantics 26, T. Stowell and E. Wehrli (eds.), 103-110. New York, etc.: Academic Press.

Schweikert, W. 2005. The Order of Prepositional Phrases in the Structure of the Clause. Amsterdam: John Benjamins.

Starke, M. 2001. Move dissolves into Merge: a theory of locality. PhD. diss. University of Geneva. http://theoling.auf.net/papers/starke_michal/

Stephens, N. M. 2006. Norwegian when-clauses. In Proceedings of the LFG06 Conference, M. Butt and T. Holloway King (eds.). Stanford: CSLI Publications. http://clslipublications.stanford.edu/

Tomaszewicz, B. 2009. Subjunctive mood in Polish. In Studies in Formal Slavic Phonology, Morphology, Syntax, Semantics and Information Structure. Proceedings of FDSL 7, Leipzig 2007 (= Linguistik International; 21), G. Zybatow, U. Junghanns, D. Lenertová, P. Biskup (eds.), 221-234. Frankfurt am Main: Peter Lang.

Watanabe, A. 1993. Larsonian CP recursion, factive complements, and selection. NELS 23, 523-537.

Whitman, J. 1989. Topic, modality, and IP structure. In Proceedings of the Third Harvard Workshop on Korean Linguistics, S. Kuno et al. (eds.), 341-356. Seoul: Hanshin.

Wiklund, A.-L. 2009. In search of the force of dependent V2: A note on Swedish. Working Papers in Scandinavian Syntax 83: 27-36.

Zagona, K. 2007. On the syntactic features of epistemic and root modals. In Coreference, Modality and Focus, L. Eguren, and O. Fernández Soriano (eds.), 221-236. Amsterdam: John Benjamins. 
Lieven Danckaert's research is funded by BOF grant nr. B/08330/02 -

BOF07/DOC/304.Liliane Haegeman's research is funded by FWO Belgium as part of project 2009Odysseus-Haegeman-G091409. We thank the audience of CGSW Brussels 2009, Karen Declercq and three anonymous reviewers for their very helpful comments.

As pointed out by one anonymous reviewer for this volume, V2 in Scandinavian also patterns with MCP (Bentzen et al 2007a,b; Wiklund 2009 and many others). Obviously we would hope that the analysis proposed here will ultimately derive the distribution of V2 in embedded clauses. For reasons of space we cannot discuss this issue here.

There is considerable variation among informants.

Thanks to Anna Roussou for the Modern Greek data. See also Anagnostopolou (1997).

We will return to the availability of clefting in temporal and conditional clauses in future work. Let us just say here that with Belletti (2009: chapter 10) we assume that clefting implicates a lower vP- related periphery.

Emonds (1976: 61-4) discusses these data in the light of a general discussion of the distribution of adjuncts. He tentatively proposes that such adjuncts are to be analysed like parentheticals.

See Emonds (1970, 1976), Culicover (1991), Browning (1996), and for CLLD Delfitto (2002: 57-8). Two remarks are in place here:

(i) The merge site might be Rizzi’s ModP (2001).

(ii) As shown by comparative work, adjuncts with local construal may also be topics or foci. See Aboh (2004) on the Gungbe LP and Endo (2008) on Japanese. Both authors show that circumstantial adjuncts may but need not be associated with the specialized topic marker. For reasons of space we cannot go into this here.

But see Benincà and Polletto (2004: 57), Samek-Lodovici (2007) on Foc>Top.

Emonds (1976) proposes that there is only one application of root transformations per sentence. This would correctly exclude the ungrammatical (29b). To exclude argument fronting in adverbial clauses one could then assume that these independently involve a root transformation, i.e, are - in our terms derived by operator fronting, as is to be argued below.

Thanks to Amelie Rocquet for help with the German examples.

See also Barbiers (2007: 102-10) for arguments from Dutch, and Den Dikken (2006: 729). But see Roberts and Roussou (2002:41) and Rizzi 2001) for a different account for embedded yes-no questions. In a different context, this point is made in Ingham (2008).

For one reviewer of this volume, the presence of only is required in this example. However, a googlesearch produces examples such as the following:

(i) Whales have bumps on their fins. It was recently that scientists figured out that the bumps actually improved their hydrodynamics. http://forum.woodenboat.com/archive/index.php/t102295.html

Also note that even WITH only the higher modal adverbs cannot be focused:

(ii) *It is only probably/obviously that he left.

Obviously this issue does deserve further study but it is sufficient in the present to establish the contrast that we want to make here between modal and temporal adjuncts.

Thanks to M. Lluisa Hernanz for judgements.

Hernanz $(2007 a, b)$ shows that bien is incompatible with temporal adverbial clauses.

On the other hand, another subset of the expressions of emphatic polarity are incompatible with all embedding. See Martins (2006:8) on verb doubling in European Portuguese and Kandybowicz (2008) on Nupe ni: for examples. 